\title{
Somatic Gene Transfer of Nerve Growth Factor Promotes the Survival of Axotomized Septal Neurons and the Regeneration of Their Axons in Adult Rats
}

\author{
Michael D. Kawaja, ${ }^{1}$ Michael B. Rosenberg, ${ }^{2}$ Kazunari Yoshida, ${ }^{1}$ and Fred H. Gage ${ }^{1}$ \\ Departments of ${ }^{1}$ Neurosciences and ${ }^{2}$ Pediatrics, University of California at San Diego, La Jolla, California 92093-0624
}

Intracerebral grafts consisting of primary fibroblasts genetically engineered to express NGF were used to assess the regenerative capacity of cholinergic neurons of the adult rat septum. Our data reveal that NGF-producing grafts sustain a significantly higher proportion of NGF receptor-immunoreactive septal neurons following axotomy $(\sim 65-75 \%)$ than do grafts of noninfected fibroblasts. In addition, NGF promotes the regeneration of septal axons. Following the ablation of cholinergic septal projections to the hippocampus, NGF-producing grafts placed within the lesion cavity contain large numbers of AChE-positive axons; control grafts, on the other hand, lack such cholinergic axons. Ultrastructural examination reveals that unmyelinated axons within NGF-producing grafts use many different substrates for growth, including astrocytes and components of the extracellular matrix. Grafts of control fibroblasts possess the same cellular and matrix substrates but contain only a small population of axons, probably of peripheral origin. AChE-positive axons growing through NGF-producing grafts provide a new topographically organized input to the deafferented hippocampal dentate gyrus. Furthermore, regenerating septal axons terminate predominantly on the dendritic processes of granular neurons. The dentate gyrus ipsilateral to grafts of noninfected fibroblasts, on the other hand, remains devoid of AChE-positive fibers. From these results, we conclude that the availability of NGF is a necessary requirement to sustain axotomized cholinergic septal neurons and to promote axon regeneration and cholinergic reinnervation of dentate granular neurons by these lesioned neurons. The presence of many permissive substrates (e.g., astrocytes, basal lamina, and collagen) alone, however, is not sufficient to induce axon regrowth from adult septal neurons.

Genetic engineering of cultured cells is a useful approach to supplement or augment deficiencies of enzymes or enzyme products due to disease or damage (Anderson, 1984; Friedmann,

\footnotetext{
Received Aug. 23, 1991; revised Feb. 3, 1992; accepted Feb. 25, 1992.

We thank Dr. Theodore Friedmann for his continued collaboration and critical comments on the manuscript. We also thank Mrs. B. Miller, Mr. S. Forbes, and Ms. B. Mason for their technical assistance. This research was supported by grants from the Pew Foundation, the McKnight Foundation, and the NIH (AG08514 and PHS NS28121). M.D.K. is a recipient of a Medical Research Council of Canada fellowship.

Correspondence should be addressed to Dr. Michael D. Kawaja, Division of Molecular Immunology and Neurobiology, Room 854, Mount Sinai Hospital Research Institute, 600 University Avenue, Toronto, Ontario, Canada M5G 1X5. Send reprint requests to Dr. Fred H. Gage at the above address.

Copyright (C) 1992 Society for Neuroscience $0270-6474 / 92 / 122849-16 \$ 05.00 / 0$
}

1989). For systemic applications, studies to date have revealed that a variety of cell types may be used as donor populations for gene transfer in vitro and subsequent implantation (Seldon et al., 1987a,b; St. Louis and Verma, 1988; Palmer et al., 1989). Both immortalized cell lines and primary cells genetically modified using retroviral vectors in vitro continue to synthesize and secrete the transgene product after grafting into the body cavity (Palmer et al., 1987, 1989; St. Louis and Verma, 1988). It has been proposed that genetic modification of cells may also serve as an alternative means of supplementing deficient enzymes (e.g., tyrosine hydroxylase) or augmenting growth factors (e.g., NGF) within the damaged or aged mammalian brain (Gage et al., 1987). Previous investigations have shown that immortalized cell lines, including rat 208F fibroblasts, mouse NIH-3T3 fibroblasts, and rat $\mathrm{C} 6$ glioma, can be genetically engineered to express transgenes in vitro (Rosenberg et al., 1988; Wolf et al., 1988; Shimohama et al., 1989; Wolff et al., 1989; Horellou et al., 1990; Strömberg et al., 1990). As observed following systemic implantation, immortalized cells grafted within the CNS often give rise to tumors (Shimohama et al., 1989; Horellou et al., 1990). Using primary cells is one approach to circumvent the problem of tumorigenesis after intracerebral grafting. Recent data from our laboratory have revealed that autologous and isologous grafts of primary skin fibroblasts can survive up to 6 months following implantation within the rat striatum (Kawaja et al., 1991; Kawaja and Gage, 1992). Also, the growth of these grafts is negligible between 3 and 8 weeks in vivo; the grafts neither form tumors nor atrophy. Finally, expression of transgenes by genetically modified primary fibroblasts can be detected up to 10 weeks after intracerebral implantation (Fisher et al., 1991). Together, these results provide encouraging evidence for the successful use of primary fibroblasts for gene transfer and subsequent implantation within the mammalian brain.

Previous studies have revealed that genetically engineered immortalized fibroblasts (rat 208F and mouse NIH-3T3) expressing the transgene for NGF sustain axotomized cholinergic neurons within the rat septum (Rosenberg et al., 1988; Strömberg et al., 1990). There, cholinergic neurons appear to be highly dependent upon the availability of ncurotrophic factors for survival following perturbation, since lesion-induced retrograde degeneration of these neurons may be prevented by infusing NGF into the ventricular cavity immediately adjacent to the damaged septum (Hefti, 1986; Williams et al., 1986; Kromer, 1987; Gage et al., 1988a; Montero and Hefti, 1988). To obviate concerns of tumor formation and possible immune rejection so often associated with immortalized cells grafted within the CNS, we have focused on using primary skin fibroblasts for the in- 
tracerebral delivery of NGF; the donor and recipients of these cells are from the same inbred strain of rats (e.g., Fischer 344). In the first part of this investigation, we used a similar experimental paradigm as Rosenberg et al. (1988) and Strömberg et al. (1990) to determine whether primary cells, genetically modified to produce NGF, are capable of transgene production in vivo, and thereby able to provide trophic support to perturbed cholinergic septal neurons. To address this issue, NGF-producing and noninfected primary fibroblasts were either placed directly within the septal parenchyma near the somata of axotomized neurons or suspended within a collagen matrix and placed in the lesion cavity. In the second part, we sought to determine the role of NGF in the regeneration of lesioned axons in the adult CNS. While we have previously found that intracerebral grafts of NGF-producing skin fibroblasts could inducc axonal sprouting (Kawaja and Gage, 1991b), several other questions remain unaddressed: (1) can these grafts promote axon regeneration among NGF-sensitive neuronal populations following axotomy, (2) can these grafts provide a suitable environment for axonal growth, and (3) can regenerating axons arising from NGF-producing grafts reinnervate target sites within the adult brain? To answer these questions, we have taken a new approach to assess the importance of NGF in the regenerative capacities of rat septal neurons after axotomy (i.e., primary skin fibroblasts genetically modified to express NGF were suspended within a collagen matrix and placed in the lesion cavity following ablation of septal axons). Here we will provide data showing that collagen/fibroblast matrices can serve as both a cellular source of NGF and a conducive "bridging" environment for septal axons regrowing toward the deafferentated hippocampus.

\section{Materials and Methods}

\section{Generation and maintenance of NGF-producing cells}

Primary skin fibroblasts were obtained from biopsies of the ventral abdominal wall of a female Fischer 344 rat anesthetized with a mixture of ketamine $(75 \mathrm{mg} / \mathrm{kg})$, xylozine $(4.0 \mathrm{mg} / \mathrm{kg})$, and acepromazine $(5.6$ $\mathrm{mg} / \mathrm{kg}$ ) (Sedgwick, 1980). These cells were grown under standard culture conditions, fed Dulbecco's modified Eagle's medium (DMEM), and split $1: 3$ once confluent. We used retroviral vectors containing the cDNA for mouse $\beta$-NGF to infect primary cells in culture, according to Rosenberg et al. (1988). The infected cells were then selected with the neomyocin analog G418. Both infected and noninfected fibroblasts were maintained under similar culture conditions for up to 16 passages. Twenty-four hours prior to isolating the cells for intracerebral implantation, fresh medium was added to the cultures. A two-site immunoassay (antisera and reagents obtained from Boehringer-Mannheim) was used to determine the levels of NGF production (that found within the cells) and secretion (that found within the media after $24 \mathrm{hr}$ ) by infected and noninfected cells, at low and high passages.

\section{Northern blot analysis}

Using the method of Chomczynski and Sacchi (1987), total cellular RNA was isolated from (1) Ratl immortalized fibroblasts and primary skin fibroblasts infected with retroviral vectors containing the cDNA for mouse NGF, (2) primary skin fibroblasts infected with retroviral vectors containing the gene for Escherichia coli $\beta$-galactosidase, (3) noninfectcd Ratl and primary skin fibroblasts, and (4) male mouse submaxillary gland. The RNA samples were separated on a $1.2 \%$ agarose gel containing $1.85 \%$ formaldehyde and transferred to a charged-modified nylon membrane by vacuum blotting. Following transfer, RNA was cross-linked to the membrane with ultraviolet light. The blot was prehybridized for $2 \mathrm{hr}$ at $42^{\circ} \mathrm{C}$ in a solution containing $50 \%$ deionized formamide, $5 \times$ Denhardt's reagent, $5 \times$ SSPE, $0.5 \%$ SDS, and $100 \mu \mathrm{g} /$ $\mathrm{ml}$ sheared herring sperm DNA.

A double-stranded DNA probe for mouse NGF was prepared by isolating the full-length coding region from plasmid $\mathrm{pSPN}^{\prime} 3^{\prime}$ as a 1 kilobase (kb) PstI fragment (Wolf et al., 1988) and labeling $20 \mathrm{ng}$ by the random primer method (according to the protocol from the manufacturer, Bethesda Research Labs). The labeled DNA was denatured by boiling, one-third was added directly to the prehybridization solution, and hybridization took place for $16 \mathrm{hr}$ at $42^{\circ} \mathrm{C}$. The blot was then washed at high stringency $\left(0.1 \times \mathrm{SSC}\right.$ at $\left.65^{\circ} \mathrm{C}\right)$ for $30 \mathrm{~min}$ and exposed to $\mathrm{x}$-ray film for $2.5 \mathrm{hr}$.

\section{Preparation of cells for implantation}

All primary fibroblasts used for intracerebral grafting purposes were harvested at postconfluence. The cultures were first rinsed in phosphatebuffered saline and then in trypsin; the number of cells was determined using a Coulter counter. Two different approaches were taken to graft primary skin fibroblasts into the damaged adult rat brain. First, infected and noninfected control cells were suspended in a grafting solution of phosphate-buffered saline supplemented with $1 \mu \mathrm{g} / \mathrm{ml}$ of $\mathrm{MgCl}_{2}$ and $\mathrm{CaCl}_{2}$, and $0.1 \%$ glucose. Second, a total of $10^{6}$ infected and noninfected cells were suspended and aliquotted in $4.5 \mathrm{ml}$ of DMEM. Type I rat tail collagen (Sigma, St. Louis, MO) was dissolved with $0.1 \%$ acetic acid for a final concentration of $3 \%$ collagen. Sodium hydroxide $(0.1 N, \sim 300$ $\mu 1)$ was added to the cell suspension to neutralize the medium. The collagen was then added to the cell suspension (for a final concentration of $1 \%$ collagen), mixed, and aliquotted into centrifuge tubes. The collagen/fibroblast matrices were incubated for $48 \mathrm{hr}$ at $37^{\circ} \mathrm{C}$ in medium.

Several parameters for choosing cells for intracerebral grafting were consistently followed: (1) infected and noninfected cells selected for implantation wcrc always taken at similar passage numbers for cach surgical session; (2) cells at a lower passage (7-9) were preferentially used over those at a higher passage (14-16), due in part to the higher levels of NGF production among infected cells (see Results); and (3) noninfected cells were used as a control population, rather than cells genetically engineered to express non-neural transgenes (e.g., primary fibroblasts containing $E$. coli $\beta$-galactosidase cDNA), so that we could more closely compare our results to those previously reported by Rosenberg et al. (1988) and Strömberg et al. (1990).

\section{Surgery and implantation of cells}

Sixty-six female Fischer 344 rats (weighing approximately 180-200 gm at the time of surgery) were anesthetized with a mixture of ketamine $(75 \mathrm{mg} / \mathrm{kg})$, xylozine $(4.0 \mathrm{mg} / \mathrm{kg})$, and acepromazine $(5.6 \mathrm{mg} / \mathrm{kg})$. The animals were placed in a Kopf stereotaxic frame, their heads were shaved, and antiseptic was applied. Twenty-two animals first received stereotaxic placements of either NGF-producing $(n=10)$ or noninfected ( $n$ $=12$ ) primary skin fibroblasts into the posterior/medial septal area unilaterally. A total of $2 \times 10^{5}$ cells $/ \mu$ l suspended in $1.5 \mu \mathrm{l}$ of grafting solution was injected per site; these intraccrebral grafts will be referred to as suspension grafts. Then, unilateral aspiration lesions through the overlying cingulate cortex and fimbria-fornix (FF) pathway were performed under stereoscopic vision. These animals were killed 4 weeks after surgery. Another 40 female animals received similar unilateral lesions of the cingulate cortex and FF pathway, following which pieces of the collagen/fibroblast matrices (approximately $2-3 \mathrm{~mm}^{3}$ in size) were placed into the wound cavity. These animals were killed 4 or 8 weeks after surgery. Another four animals received only cingulate cortex and FF lesions, and these animals survived for 4 weeks after surgery.

\section{Tissue preparation}

Following a 4 week postoperative survival period, those animals with suspension grafts or with lesions alone were deeply anesthetized (as above) and perfused transcardially with a solution of $4 \%$ paraformaldehyde in $0.1 \mathrm{~m}$ phosphate buffer ( $\mathrm{pH} \mathrm{7.3)}$. The brains were removed and stored in the same fixative overnight at $4^{\circ} \mathrm{C}$, and then in $30 \%$ phosphate-buffered sucrose for $3 \mathrm{~d}$ at $4^{\circ} \mathrm{C}$. The brains were sectioned in a coronal manner ( $40 \mu \mathrm{m}$ thick) on a freezing microtome and collected in $0.1 \mathrm{~m}$ Tris-buffered saline (TBS; $\mathrm{pH} \mathrm{7.3)}$. Alternate sections through the septal area were stained immunohistochemically for NGF receptor and fibronectin (see below). Sections through the septum and lesion site were stained for Nissl substance using aqueous $0.5 \%$ thionin. Sections through the lesion cavity and hippocampus were stained histochemically for acetylcholinesterase (AChE) using a modified method of Hedreen et al. (1985).

Following postoperative periods of 4 and 8 weeks, those animals with collagen/fibroblast grafts were deeply anesthetized (as above) and perfused transcardially with $4 \%$ paraformaldehyde in $0.1 \mathrm{M}$ phosphate buffer ( $\mathrm{pH}$ 7.3). For those cases processed for electron microscopic exam- 
ination, $0.1 \%$ glutaraldehyde was added to the buffered $4 \%$ paraformaldehyde fixative. The brains were removed, postfixed overnight at $4^{\circ} \mathrm{C}$, and then placed in $30 \%$ phosphate-buffered sucrose for 3 d at $4^{\circ} \mathrm{C}$ (brains examined at the ultrastructural level were not stored in sucrose). The cryoprotected brains were cut in a coronal fashion (40 $\mu \mathrm{m}$ in thickness) on a freezing microtome, and the uncryoprotected brains were cut in a coronal fashion ( $50 \mu \mathrm{m}$ in thickness) on an Oxford vibratome. All sections were collected in TBS. Alternate sections through the septal area were stained immunohistochemically for NGF receptor. Sections through the lesion cavity and collagen/fibroblast grafts were stained for Nissl substance and AChE, as well as immunostained for NGF receptor, laminin, glial fibrillary acidic protein (GFAP), and tyrosine hydroxylase (TH). Sections through the hippocampus were stained for AChE, NGF receptor, and TH. Unstained sections (50 $\mu \mathrm{m}$ in thickness cut on a Vibratomc) through the collagen/fibroblast grafts and AChE-stained sections through the hippocampus were also processed for ultramicrotomy (see below).

\section{Immunohistochemistry}

Immunohistochemical detection of NGF receptor, TH, and GFAP. The sections were initially treated in a solution of $0.6 \%$ aqueous hydrogen peroxide for $30 \mathrm{~min}$, briefly rinsed in TBS, and incubated in a solution containing TBS, 3\% normal horse serum, and $0.25 \%$ Triton-X for $1 \mathrm{hr}$ (this solution was used to dilute all antibodies). The sections were then incubated for $48 \mathrm{hr}$ at $4^{\circ} \mathrm{C}$ in a solution containing one of the following antibodies: monoclonal 192 IgG to NGF receptor (Chandler et al., 1984; 1:100 dilution), monoclonal IgG to TH (Boehringer-Mannheim; 1:250), and monoclonal IgG to GFAP (Amersham; 1:100). Control sections were incubated in solutions lacking primary antisera. All sections were then rinsed in buffer and incubated in biotinylated horse anti-mouse IgG (1:167) for $1 \mathrm{hr}$ at room temperature. After another rinse with buffer, the sections were incubated in avidin-biotin complex (Vector Laboratories) for $1 \mathrm{hr}$. They were then rinsed again and reacted in a solution containing $0.025 \%$ diaminobenzidine tetrahydrochloride, $0.5 \%$ nickel chloride, and $0.018 \%$ hydrogen peroxide in TBS for $5 \mathrm{~min}$. The reaction was stopped by rinsing the sections in buffer.

Immunohistochemical detection for laminin and fibronectin. The sections were initially treated with $0.6 \%$ aqueous hydrogen peroxide, rinsed, and incubated in a solution of TBS, $3 \%$ normal goat serum, and $0.25 \%$ Triton-X. The sections were then incubated in the same solution as above with the addition of either rabbit anti-human fibronectin (1:2000 dilution) or rabbit anti-human laminin $\operatorname{IgG}$ (1:800 dilution) for $48 \mathrm{hr}$ at $4^{\circ} \mathrm{C}$. Control sections were incubated in a solution lacking the primary antisera. They were then rinsed and incubated in biotinylated goat antirabbit (1:220) for $1 \mathrm{hr}$ at room temperature. After another rinse, the sections were incubated in avidin-biotin complex for $1 \mathrm{hr}$ and reacted as above.

After the diaminobenzidine reaction, all sections were mounted on chrome alum-gelatin-coated slides, dehydrated through a graded series of ethanols, coverslipped, and viewed under bright-field optics.

\section{Morphometric analysis}

Five sections ( $40 \mu \mathrm{m}$ in thickness) through septal arca stained immunohistochemically for NGF receptor were selected for neuronal cell counting. These sections were approximately $300,420,540,660$, and $780 \mu \mathrm{m}$ rostral to the decussation of the anterior commissure. The medial septum was defined as that area lying above a line drawn between the midportions of the anterior commissure, and bound laterally by the ventricles. A grid $(0.5 \times 0.5 \mathrm{~mm})$ was used to count immunoreactive septal neurons at $10 \times$ magnification. At this magnification each side of the septal area occupied 12 optical fields, and all immunoreactive cell bodies within each of these fields were counted; only those neurons situated along the midline were not included. Group differences comparing the percentage of NGF receptor-positive cell survival per animal for each group of animals were assessed by a one-way ANOVA.

\section{Morphological analysis of cell size}

The size of immunoreactive perikarya in those animals with either NGF-producing or control suspension grafts was determined using a Q-2 image analysis system (Olympus Corp.). Using a $10 \times$ objective lens, areas within the medial septum were selected randomly, and NGF receptor-positive somata were sized at that same level, both ipsilateral and contralateral to the FF lesion. These measurements of cell size were taken from three groups: (1) animals with grafts of NGF-producing fibroblasts, (2) animals with grafts of noninfected fibroblasts, and (3) animals with no grafts. Group differences comparing cell sizes per animal for each group were assessed by a one-way ANOVA. Following the same criterion used by two previous investigations from our laboratory (Armstrong et al., 1987; Gage et al., 1988a), only those unambiguous immunoreactive septal somata larger than $80 \mu \mathrm{m}^{2}$ were included in the three groups.

\section{Retrograde labeling}

Nine deeply anesthetized animals (as described above) with collagen/ fibroblast grafts of either NGF-producing $(n=5)$ or noninfected $(n=$ 4) cells received, at 8 weeks after surgery, two stereotaxic placements of rhodamine-labeled fluorescent microspheres $(200 \mathrm{nl} / \mathrm{site})$ into the dentate gyrus and CA2-3 fields in the hippocampus ipsilateral to the lesion and graft. Following a $48 \mathrm{hr}$ recovery, the animals were again anesthetized and perfused transcardially with $4 \%$ buffered paraformaldehyde. Coronal sections of the brains were cut on a freezing microtome ( $40 \mu \mathrm{m}$ in thickness), mounted on uncoated slides, and coverslipped with an aqueous mountant. Injection sites and retrogradely labeled neurons within the septal areas were visualized under fluorescence microscopy.

\section{Ultramicrotomy}

Unstained sections (50 $\mu \mathrm{m}$ in thickness) through collagen/fibroblast grafts (both NGF-producing and control) and AChE-stained sections through the dentate gyrus ipsilateral to grafts of NGF-producing and control grafts were processed for ultrastructural examination. The sections were rinsed in phosphate buffer and fixed with $1 \%$ osmium tetroxide for $2 \mathrm{hr}$ at room temperature. The sections were then rinsed in buffer, dehydrated through a graded series of methanols, cleared in propylene oxide, and embedded in a mixture of Poly/Bed and Araldite. Semithin sections (1-2 $\mu \mathrm{m}$ in thickness) through the grafts were stained with $1 \%$ toluidine blue to assess the graft morphology at the light microscope level. Ultrathin sections were cut on a Reichert Ultramicrotome, collected on copper grids, and stained with uranyl acetate and lead citrate. The sections were viewed with a JEOL CX100 transmission electron microscope. Ultrastructural examination included determining the total number of axons across 10 grid squares (two adjacent columns of five grid squares, a total area of $960 \mu \mathrm{m}^{2}$ ) in collagen/fibroblast grafts from animals receiving either NGF-producing $(n=3)$ or noninfected $(n=3)$ cells.

\section{Results}

\section{In vitro analysis of $N G F$ production and secretion}

From Northern blot analysis, the mRNA for NGF was detected in male mouse submaxillary gland and in rat primary and immortalized fibroblasts infected with retroviral vectors containing cDNA for mouse NGF (Fig. 1). Noninfected primary and immortalized fibroblasts did not express mRNA for NGF; neither did $\beta$-galactosidase-producing primary fibroblasts. As determined with the two-site immunoassay, primary skin fibroblasts infected with retroviral vectors containing the cDNA for NGF contained low intracellular levels of NGF, approximately $34 \mathrm{pg} \mathrm{NGF} / 10^{5}$ cells. These same cells, however, secreted higher levels of NGF into the culture media, approximatcly 173 and $154 \mathrm{pg} \mathrm{NGF} / \mathrm{hr} / 10^{5}$ cells after passages 7 and 16 , respectively. As revealed by these data, the amount of NGF found in the media diminished slightly after several cellular passages in vitro. For this reason, NGF-producing fibroblasts used for intracerebral implantation were usually taken at a low passage. Noninfected cells neither contained nor secreted detectable levels of NGF.

\section{Morphological assessment of suspension grafts}

The completeness of FF lesions was assessed in sections stained for Nissl substance and AChE. Also, the depletion of AChEpositive fibers ipsilateral to the ablation was evaluated in the rostral hippocampus. Septal NGF receptor-positive neurons were 


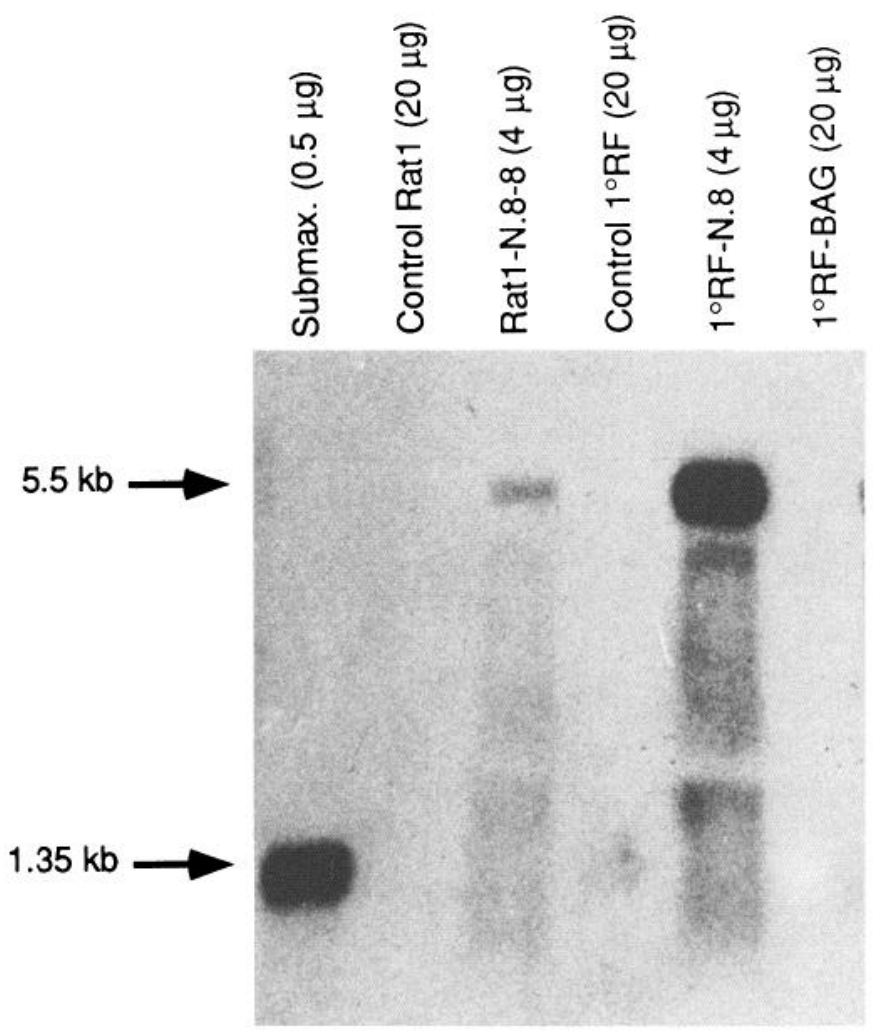

Figure 1. Northern blot analysis of mRNA for NGF among different cells and tissue. Hybridization of the probe to RNA from the male mouse submaxillary gland (Submax.) is evident. Similar hybridization is seen for Fischer rat primary skin fibroblasts genetically modified to express NGF $\left(1^{\circ} R F-N .8\right)$. Hybridization of the probe to RNA from Rat 1 fibroblasts genetically engineered to express NGF (Rat $1-N .8-8)$ is also seen, but to a lesser degree. The positively probed RNA from primary and Rat 1 fibroblasts genetically modified to express NGF is larger $(\sim 5.5 \mathrm{~kb})$ than that isolated from male mouse submaxillary gland $(\sim 1.35 \mathrm{~kb})$. This size difference is due to the presence of the retroviral sequence, including the RNA for the $\mathrm{Neo}^{\mathrm{R}}$ gene, among infected cells. Noninfected immortalized fibroblasts (Control Rat 1 ), noninfected primary skin fibroblasts (Control $1^{\circ} R F$ ), and primary skin fibroblasts genetically modified to produce $E$. coli $\beta$-galactosidase $\left(1^{\circ} R F-B A G\right)$ do not express mRNA for NGF.

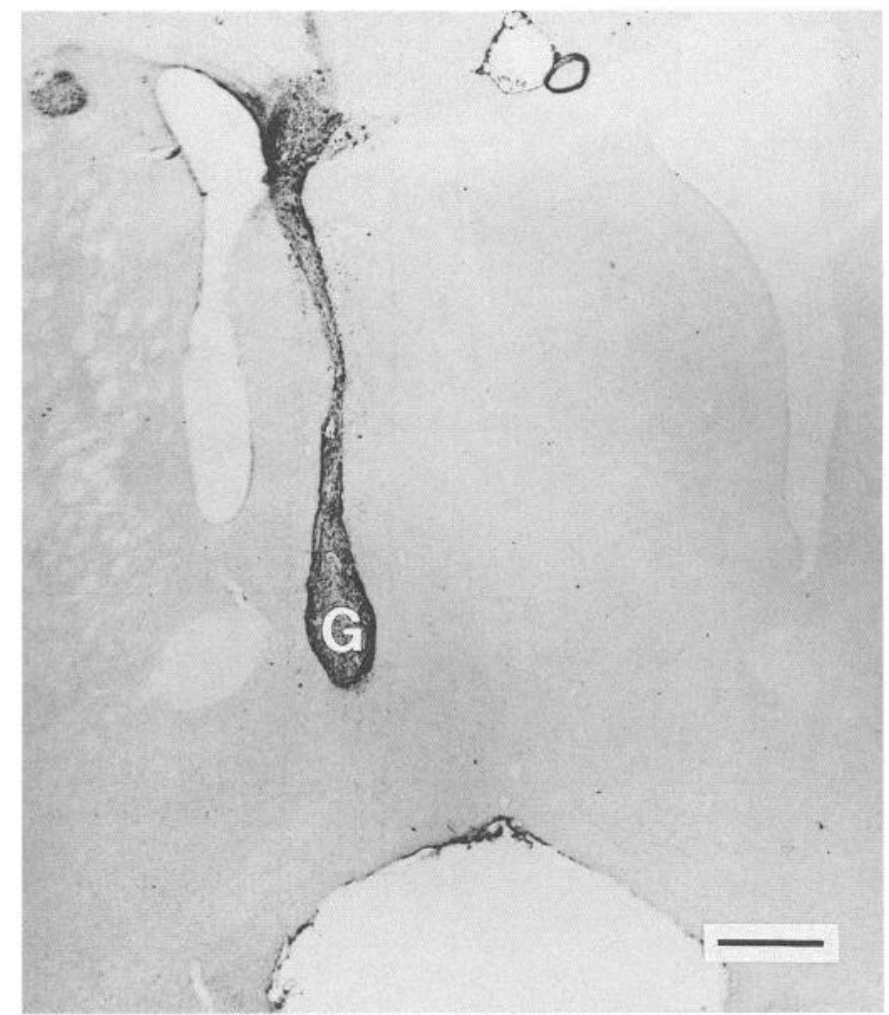

Figure 3. A section of an intraseptal graft of primary skin fibroblasts stained immunohistochemically for fibronectin, 4 weeks after surgery. The suspension graft $(G)$, situated ipsilateral to the FF lesion, displays no sign of tumor formation. Scale bar, $0.5 \mathrm{~mm}$.

assessed morphologically and morphometrically only in those animals with a complete FF transection and showing a total loss of AChE-positive fibers in the ipsilateral rostral hippocampus (Fig. 2).

Four weeks after implanting primary skin fibroblasts into septum, sections through this area were stained for Nissl substance, fibronectin, and NGF receptor. Suspension grafts of both NGFproducing and noninfected fibroblasts were evident within the
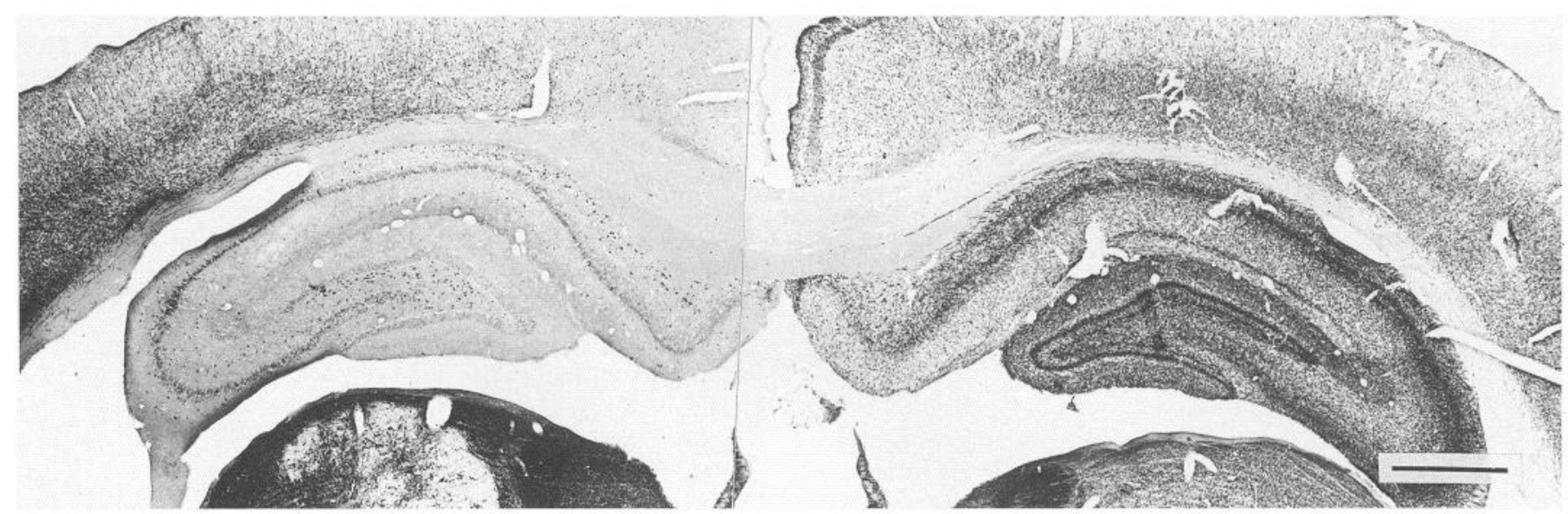

Figure 2. A section of the rostral hippocampus stained histochemically for AChE, 4 weeks after surgery. The right hippocampus possesses a rich plexus of topographically organized AChE-positive axons, whereas the left hippocampus, ipsilateral to the FF lesion, is completely devoid of labeled axons. Scale bar, $1.0 \mathrm{~mm}$. 

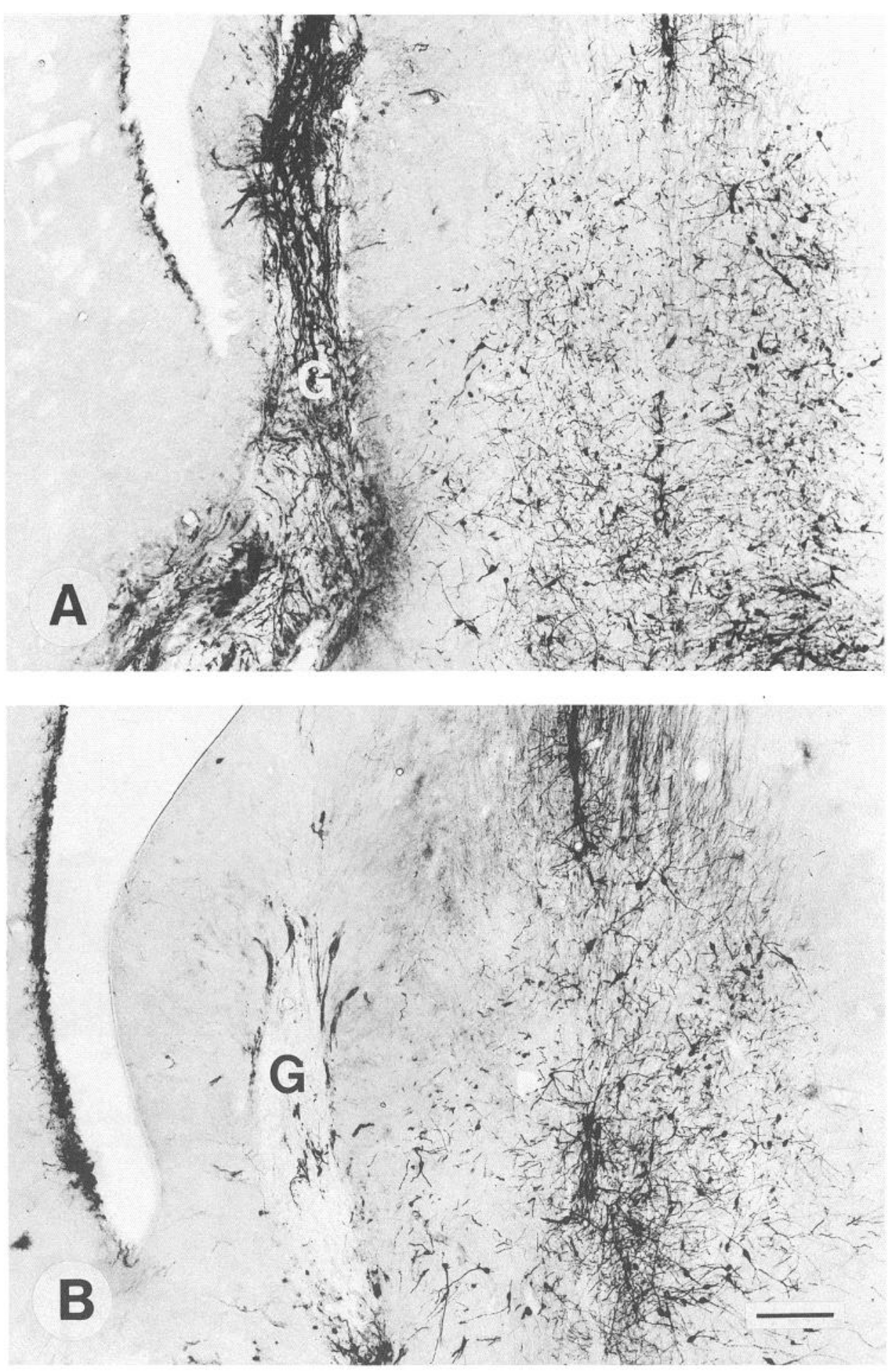

Figure 4. Sections of the medial septum stained immunohistochemically for NGF receptor, 4 weeks after surgery. Ipsilateral to the FF lesion, suspension grafts $(G)$ of NGF-producing cells $(A)$ are filled with immunostained profiles, whereas grafts of noninfected cells $(B)$ lack immunoreactivity. Also, note that the population of axotomized immunostained neurons is larger ipsilateral to the graft of NGF-producing cells than to the graft of noninfected cells. Scale bar, $200 \mu \mathrm{m}$. neuropil of the posterior or medial septal nuclei. The grafts contained fibroblasts with elongated nuclei, as well as an extracellular matrix immunostained for fibronectin (Fig. 3). Capillaries were also evident within these intraparenchymal fibroblast grafts. Despite variations in their size and position within the septal areas, all grafts were situated ipsilateral to the lesioned FF. Suspension grafts of NGF-producing cells also possessed a robust plexus of axons stained immunohistochemically for NGF receptor (Fig. 4A). With the exception of those grafts exposed to the lesion cavity, implants of noninfected cells were usually devoid of these immunoreactive processes (Fig. $4 B$ ).

\section{Morphological assessment of collagen/fibroblast grafts}

Only those animals with a complete unilateral cingulate cortex/ FF lesion and possessing a collagen/fibroblast graft in the cavity were assessed for the following: (1) saving of NGF receptorimmunoreactive septal neurons following axotomy, (2) neurochemical staining in the grafts and hippocampus, (3) retrograde 

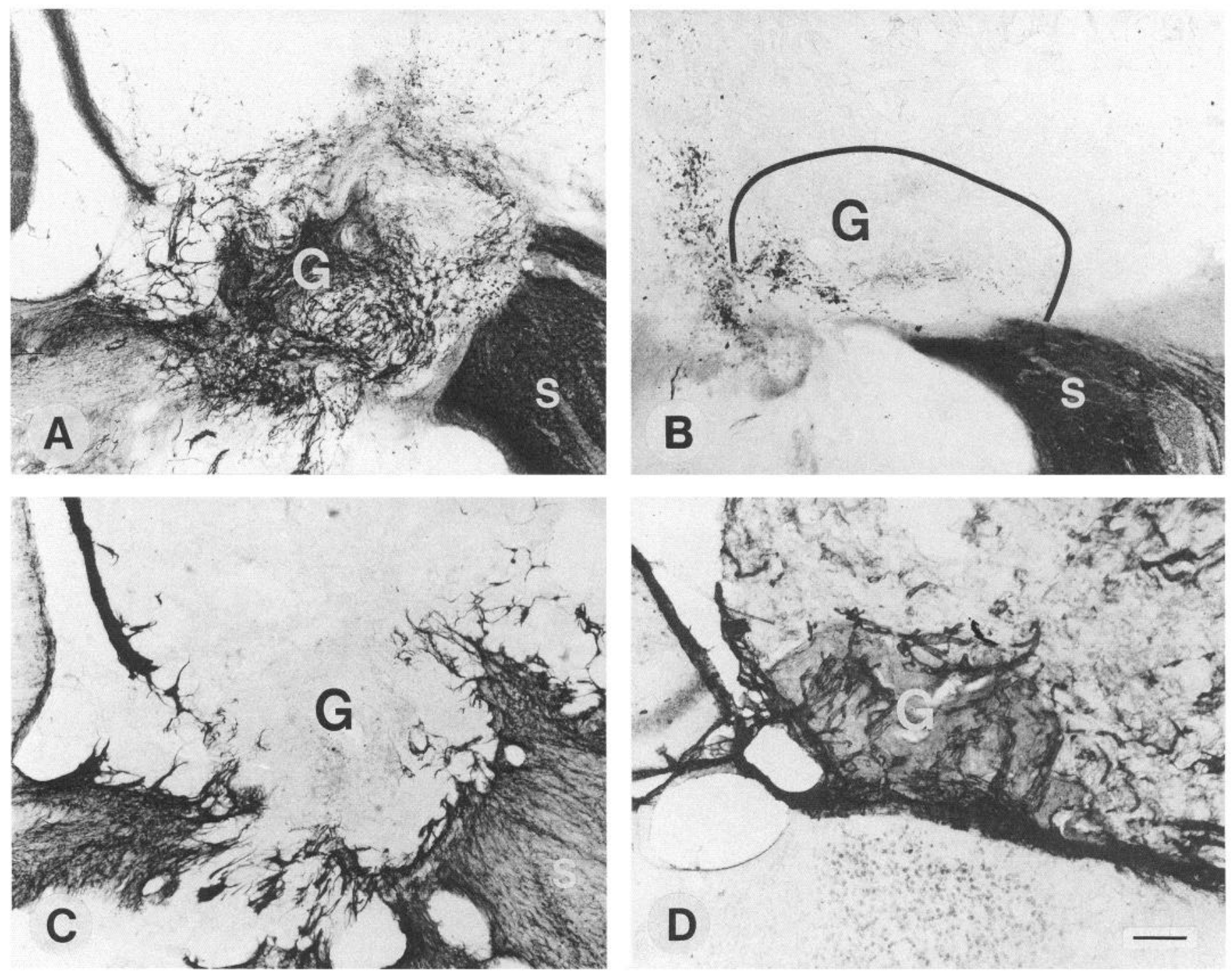

Figure 5. Immunohistochemical detection of AChE, laminin, and GFAP within collagen/fibroblast grafts, 8 weeks after surgery. $A$, Grafts $(G)$ of NGF-producing fibroblasts contain a dense array of AChE-positive axons. $B$, In contrast, grafts of noninfected fibroblasts lack AChE-positive fibers (solid line marks the outer perimeter of the graft). $C$, Immunostaining for GFAP, a subunit of intermediate filament found in astrocytes, reveals numerous immunoreactive astrocytic processes projecting from the host tissue and into the perimeter of the NGF-producing graft seen in $A$. A few GFAP-positive cell bodies are also found within the grafts. $D$, Laminin immunoreactivity reveals a robust vascular plexus within the control collagen/fibroblast graft seen in $B$. Unlike AChE staining, patterns for GFAP and laminim immunoreactivity are comparable for grafts of either NGF-producing or noninfected fibroblasts. $S$, striatum. Scale bar, $200 \mu \mathrm{m}$.

transport of fluorescent markers from the hippocampus ipsilateral to the lesion and grafts, (4) ultrastructural morphology of the grafts, and (5) ultrastructural distribution of AChE reactivity in the deafferented dentate gyrus.

Nissl staining in the collagen/fibroblast grafts containing either NGF-producing or noninfected cells revealed two distinct graft regions: an inner dense collagenous core and a looser reticular pattern of collagen surrounding the central portion. Toluidine staining of semithin plastic sections revealed that all grafts were composed of a variety of different cell types within and surrounding the dense folds of collagen, including fibroblasts, lymphocytes, mast cells, plasma cells, and endothelial cells of capillaries. One noticeable difference between the two types of grafts was the pattern of AChE staining. Grafts of NGFproducing fibroblasts with a visible connection to the septum stained moderately to intensely for $\mathrm{AChE}$, especially at the pe- rimeter of the implants, 4 and 8 weeks after implantation (Fig. $5 A$ ). In those cases where no connection was evident between the septum and collagen/fibroblast matrices, AChE-positive axons were not observed within the NGF-producing grafts. Grafts of control fibroblasts contacting the septum also lacked AChE reactivity, at both 4 and 8 weeks (Fig. $5 B$ ). Although AChE staining within NGF-producing and control grafts was markedly different, both types of grafts possessed similar patterns of immunostaining for GFAP, laminin, and TH. Astrocytic processes stained for GFAP, a subunit of intermediate filaments, extended from the damaged neural tissue around the wound cavity and penetrated into the outer aspects of the grafts. Occasionally, GFAP-positive cells were found within the grafts as well (Fig. $5 C$ ). Laminin immunostaining of grafts of NGF-producing and noninfected fibroblasts revealed an extensive host-derived vascular network (Fig. 5D). Also, elongated laminin-immunoreac- 
Table 1. Percentages of NGF receptor-immunoreactive septal neurons saved (contralateral vs ipsilateral) with grafts of NGF-producing fibroblasts or noninfected fibroblasts, or with no grafts, 4 and 8 weeks following unilateral FF ablation

\begin{tabular}{lll} 
& \multicolumn{2}{l}{ Postoperative survival period } \\
\cline { 2 - 3 } & 4 weeks & 8 weeks \\
\hline NGF-producing collagen/fibroblast grafts & $68 \pm 4(n=3)^{*}$ & $62 \pm 7(n=7)^{*}$ \\
Control collagen/fibroblast grafts & $47 \pm 4(n=4)$ & $47 \pm 5(n=8)$ \\
NGF-producing suspension grafts & $75 \pm 7(n=7)^{* *}$ & - \\
Control suspension grafts & $45 \pm 5(n=10)$ & - \\
No grafts & $44 \pm 8(n=3)$ & - \\
\hline
\end{tabular}

Data are presented as means \pm SD.

* Collagen/fibroblast grafts of NGF-producing cells sustain a significantly $(p<0.01)$ higher percentages of NGF receptorpositive septal neurons at 4 and 8 weeks than did collagen/fibroblast grafts of noninfected cells.

** Intraseptal grafts of NGF-producing cells maintain a significantly $(p<0.01)$ higher percentage of NGF receptorpositive septal neurons at 4 weeks than did intraseptal grafts of noninfected fibroblasts. The percentages of NGF receptorimmunoreactive neurons remaining with either control grafts or no grafts are comparable.

tive cell bodies, perhaps Schwann cells, were found within and around the dense collagen bundles of both types of grafts. Finally, all grafts possessed a sparse population of $\mathrm{TH}$-immunoreactive axons, particularly within the dense collagen bundles.

At the electron microscope level, all grafts consisted of dense collagen bundles with a loose outer reticular arrangement at 8 weeks after implantation. Fibroblasts were seen within the dense and reticular collagenous formations, and attenuated fibroblastderived processes enveloped dense bundles of collagen in both areas. Capillaries composed of nonfenestrated endothelial cells surrounded by basal lamina were found throughout the grafts. Several types of cells were also seen within the grafts, including lymphocytes, plasma cells, mast cells, and phagocytes. Astrocytes and their processes were found predominantly within the loose reticulum around the dense collagen center. The most prominent difference between grafts of NGF-producing and noninfected fibroblasts was the number of unmyelinated axons. Within an area of $960 \mu \mathrm{m}^{2}, 1625$ axons were found in a NGFproducing graft, compared with 329 axons in a control graft. Large numbers of axons were surrounded by or passed along narrow processes of astrocytes (Fig. $6 \mathrm{~A}-\mathrm{C}$ ); these astrocytic profiles were often arranged in lamellated stacks that lacked basal lamina on those membrane surfaces opposing one another. Unmyelinated axons were also found near the cell bodies of astrocytes and other cells, including fibroblasts (Fig. 6D). Still other unmeylinated axons were closely associated with the basal lamina of capillaries or found in the extracellular matrix of the NGFproducing grafts (Fig. $6 E$ ). Within grafts of either NGF-producing or noninfected fibroblasts, small numbers of unmyelinated axons enveloped by Schwann cells and their processes were evident in the loose collagenous areas (Fig. 6F). A few axons were also observed among the dense collagen bundles of both types of grafts and were usually ensheathed by attenuated glial profiles.

\section{Septal neuron savings with NGF-producing fibroblasts}

At 4 and 8 weeks after unilateral FF lesions, a striking decrease in the number of NGF receptor-positive somata within the medial septum was evident ipsilateral to the ablation (Figs. 4, 7). The number of somata ipsilateral to NGF-producing grafts, however, appeared slightly greater than that ipsilateral to control grafts. The percentages of NGF receptor-positive septal neurons sustained with NGF-producing grafts were significantly higher than with grafts of noninfected primary fibroblasts at the same time periods, for both suspension and collagen/fibroblast grafts (Table 1). Furthermore, the percentage of cell savings observed with NGF-producing cells implanted directly within the septal area was higher than with collagen/fibroblast grafts placed within the lesion cavity. Finally, the percentages of lesioned septal neurons remaining with either control grafts or no grafts were comparable.

\section{Cell size}

The size of immunoreactive perikarya ipsilateral $(n=210)$ and contralateral $(n=292)$ to FF lesions in animals with suspension grafts of NGF-producing or noninfected cells or no grafts was assessed. Four weeks after axotomy, a modest shrinkage of NGF receptor-positive neurons ipsilateral to the FF lesion was observed in all the groups. Howcver, no significant differences in the size of septal immunoreactive somata were detected among the three groups (Table 2). Furthermore, the size of cell bodies did not differ significantly between those situated ipsilateral or contralateral to the FF lesion.

\section{New axon growth into the deafferentated dentate gyrus}

The normal rat dentate gyrus possesses a dense plexus of septal axons and terminals stained for AChE and NGF receptor, arranged in a precise laminar pattern (Fig. $8 \mathrm{~A}$ ). Four weeks after a unilateral FF ablation and placement of collagen/fibroblast matrices containing NGF-producing cells, a moderate plexus of AChE-positive axons was evident in the medial and rostral aspects of the deafferented dentate gyrus. By 8 weeks, the density of AChE-positive fibers increased markedly, yet most axons

Table 2. The mean sizes of immunoreactive septal neurons, both ipsilateral and contralateral to the FF lesion, 4 weeks after surgery

\begin{tabular}{lll} 
& \multicolumn{2}{l}{ Cell size $\left(\mu \mathrm{m}^{2}\right)$} \\
& Ipsilateral & Contralateral \\
\hline $\begin{array}{l}\text { NGF-producing } \\
\quad \text { grafts }\end{array}$ & $157 \pm 7 \quad(n=94)$ & $194 \pm 22(n=123)$ \\
Control grafts & $168 \pm 25(n=50)$ & $180 \pm 17(n=79)$ \\
No grafts & $176 \pm 16(n=66)$ & $181 \pm 14(n=90)$
\end{tabular}

Data are presented as means \pm SD. There are no significant differences in cell size among the three groups of animals, those with suspensions grafts of NGF. producing cells, those with suspension grafts of noninfected control cells, and those with no grafts. 

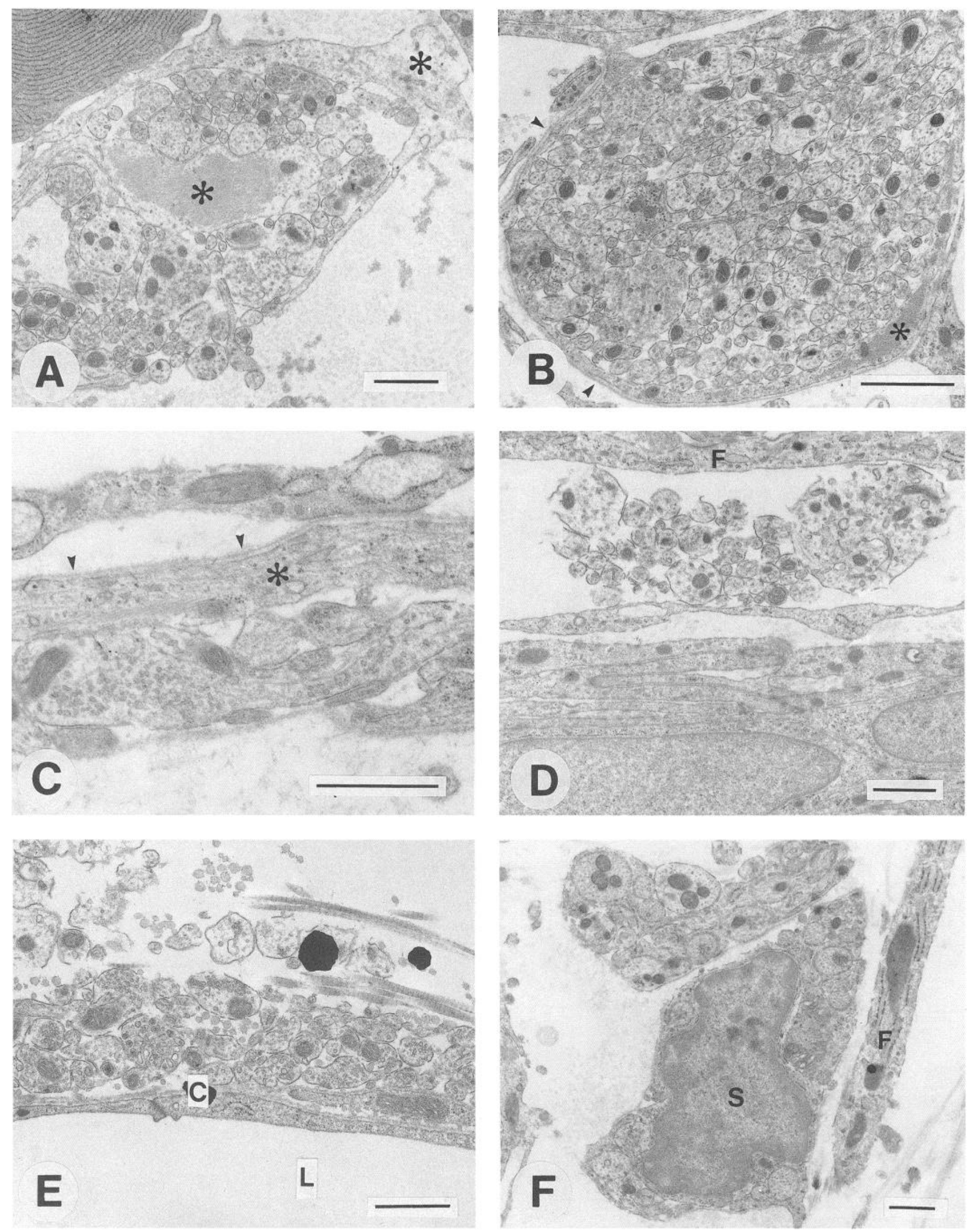

Figure 6. Ultrastructural distribution of unmyelinated axons within grafts of collagen and NGF-producing fibroblasts, 8 weeks after surgery. A$C$, Numerous axons (e.g., approximately 215 axons in $B$ ) are often associated with astrocytic processes $\left({ }^{*}\right)$ that contain intermediate filament. These 

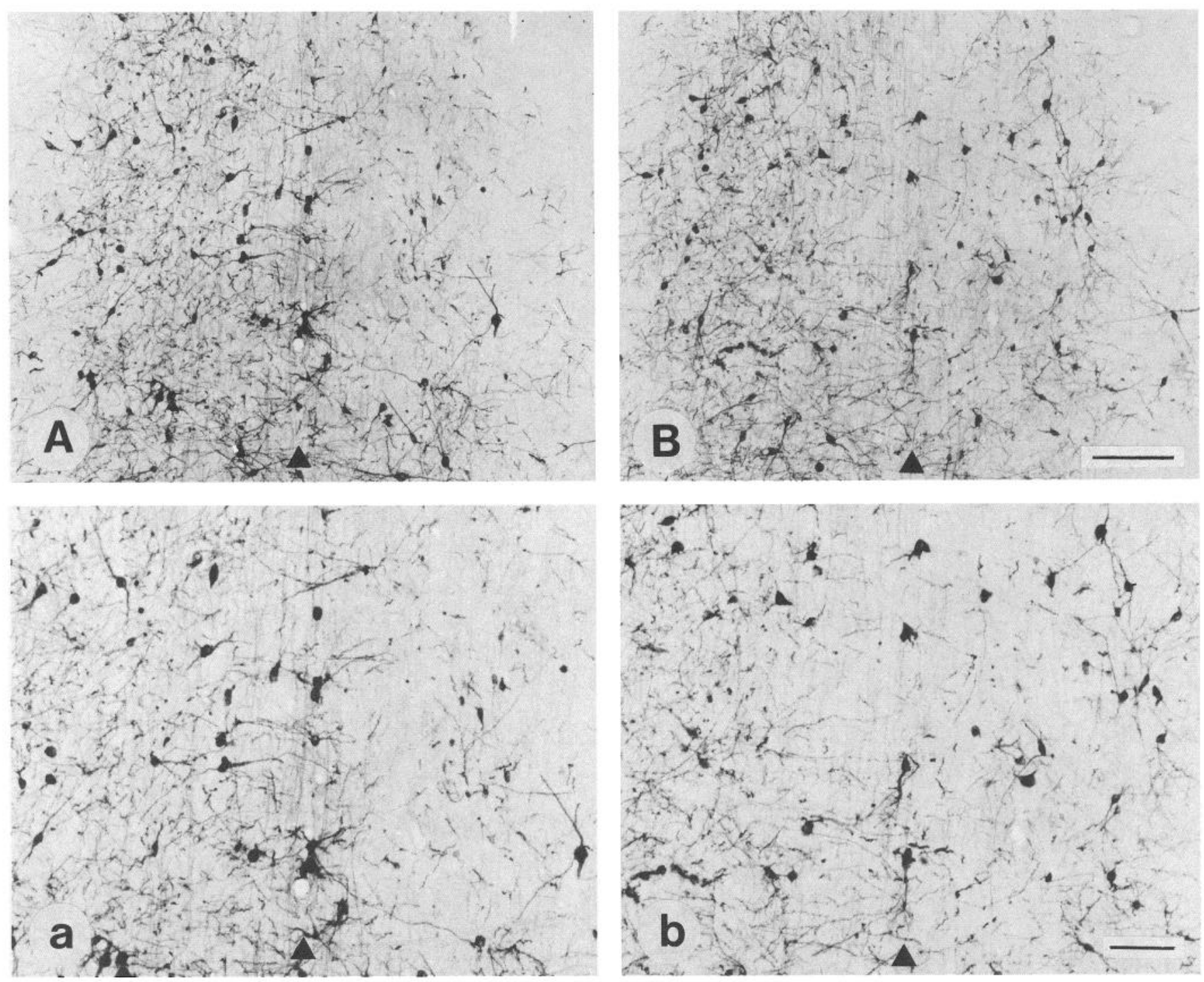

Figure 7. Sections of the medial septum stained immunohistochemically for NGF receptor, at low $(A, B)$ and high $(a, b)$ magnifications. $A$ and $a$, The population of immunostained septal neurons is dramatically reduced ipsilateral to FF lesion and a control collagen/fibroblast graft, 8 weeks after surgery. $B$ and $b$, The proportion of immunoreactive neurons ipsilateral to FF lesion and NGF-producing grafts is larger than that with control grafts, at the same postoperative period. Also, the neurons surviving with NGF-producing grafts are of comparable size to the unlesioned neurons on the contralateral side, whereas those axotomized neurons ipsilateral to control grafts appear shrunken. Septal midline indicated by arrowheads. Scale bars: $A$ and $B, 200 \mu \mathrm{m} ; a$ and $b, 100 \mu \mathrm{m}$.

were still confined to the rostromedial dentate gyrus (Fig. $8 B$ ). In certain cases, however, a robust plexus of topographically organized AChE-positive axons was seen within the dentate gyrus and extending laterally into the CA2-3 fields. Although the pattern of reinnervation was comparable to the distribution of AChE-positive septal axons in the normal undamaged hippocampus, the density of axons was usually low. Four and eight weeks after a unilateral FF transection and placement of collagen/fibroblast matrices containing noninfected cells, the deafferented dentate gyrus was completely devoid of axons stained for AChE (Fig. 8C). The distribution of axons stained immunohistochemically for NGF receptor paralleled that for AChE in all animals. Large-diameter axons immunostained for NGF receptor or TH were also found in the granular, infragranular, and polymorphic layers of the deafferented dentate gyrus (caudal portion only) in all cases at 8 weeks (Fig. $8 D$ ); these axons are reminiscent of those that originate from the superior cervical ganglion and sprout into the hippocampus following FF lesions (Batchelor et al., 1989).

The precise origin of those septal neurons that regenerated

astrocytic profiles possess basal lamina (arrowheads) on those cell surfaces facing the graft extracellular matrix. The axons are usually found apposing those astrocytic surfaces lacking a basal lamina. $D$, Axons are also seen in apposition with fibroblasts $(F)$ and other astrocyte-like cells and their processes. $E$, Basal lamina covering the endothelial cells of capillaries $(C)$ within the graft also provide a conducive surface for axon growth; collagen fibrils are distributed among the axons. $L$, lumen of the capillary. $F$, Unmyelinated axons are also enveloped within Schwann cells $(S)$ and their processes. Scale bars, $1.0 \mu \mathrm{m}$. 

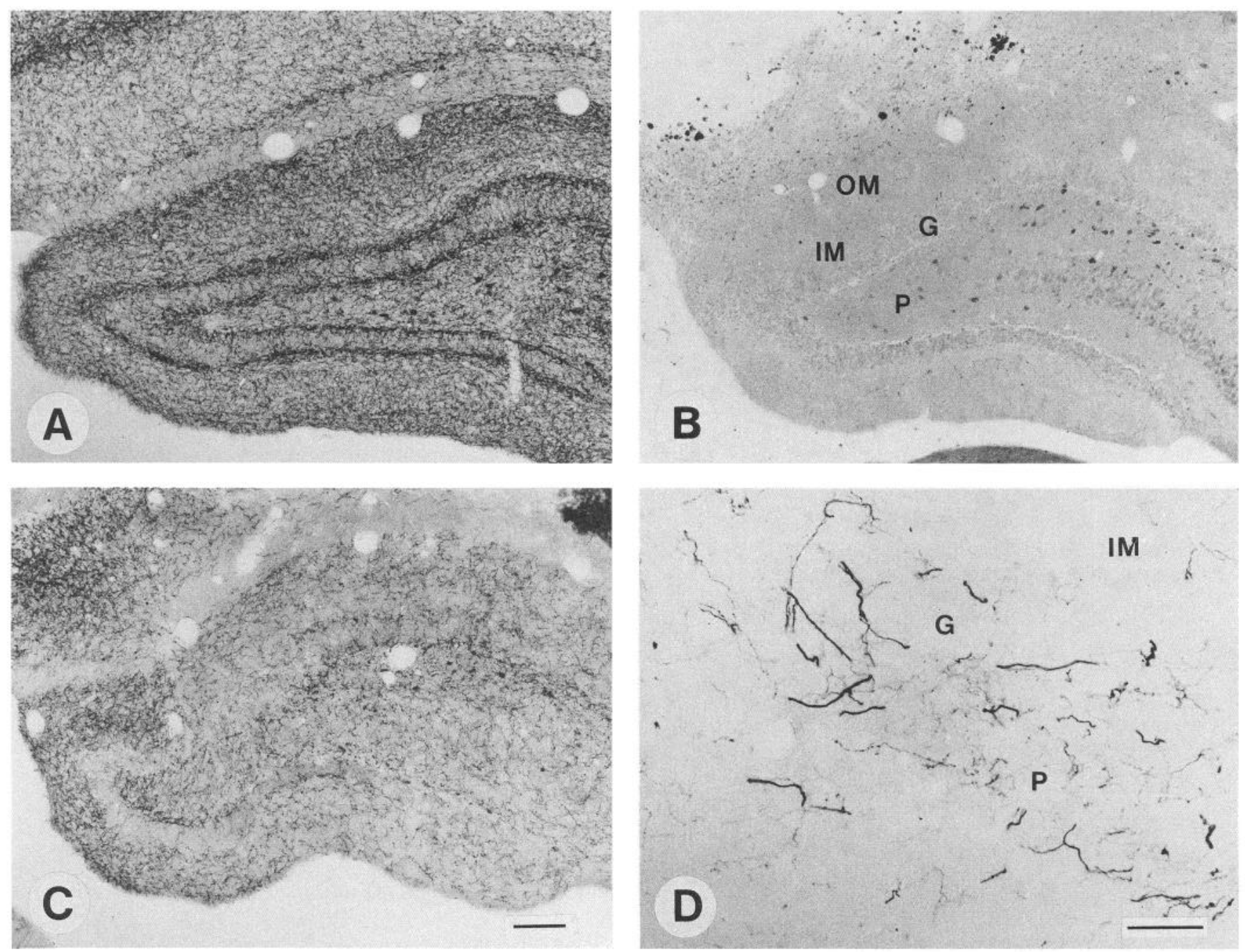

Figure 8. Distribution of neurochemically specific axons in the normal $(A)$ and deafferented hippocampus $(B-D), 8$ weeks after surgery. $A$, The normal hippocampus possesses a topographically organized input of AChE-positive fibers among the laminar divisions of the dentate gyrus. $B$, After FF ablation and implantation of control collagen/fibroblast grafts, the ipsilateral dentate gyrus is devoid of AChE-positive fibers. $C$, After FF ablation and implantation of NGF-producing collagen/fibroblast grafts, the ipsilateral dentate gyrus possesses a robust AChE-positive fiber input; the density, however, is lower than that normally observed. $D$, In all lesion cases, large-diameter sympathetic axons immunostained for NGF receptor are evident in the caudal portions of the hippocampus. $G$, granular layer; $I M$, inner molecular layer; $O M$, outer molecular layer; $P$, polymorphic layer. Scale bars: $A-C, 100 \mu \mathrm{m} ; D, 50 \mu \mathrm{m}$.

new axons following FF ablation and reinnervated the deafferented hippocampus was determined using retrograde fluorescent microspheres. At 8 weeks following unilateral FF ablation and placement of either infected or noninfected collagen/fibroblast grafts, stereotaxic injections of tracer were made in the ipsilateral dentate gyrus and CA2-3 fields. Retrogradely labeled neurons were found predominantly within the ipsilateral medial septum and diagonal band areas in those animals with NGF-producing grafts (Fig. 9A,D). A smaller number of labeled neurons were also observed in the septal midline and in the contralateral septal nuclei (Fig. 9B,C). Cases with grafts of control noninfected fibroblasts did not possess retrogradely labeled neurons in any area of the septal region.

Electron microscopic examination of the deafferented hippocampus following the placement of NGF-producing grafts revealed a sparse distribution of $\mathrm{AChE}$ reactivity within the dentate neuropil, predominantly in the molecular layers (Fig. 10). The electron-dense reaction product was localized to the plasma membranes of small-diameter unmyelinated axons and terminals containing clear spherical vesicles. AChE-positive axons were usually clustered together in groups of three or more, and these aggregates of stained axons were often found near astrocytic processes. Axon terminals possessing reactivity for AChE formed synaptic contacts with dendritic shafts and spines. The symmetry of contacts between AChE-positive terminals and dendritic profiles of granular neurons, however, was usually obscured by the localization of reaction product at the site of apposition. Since semithin sections of the deafferented dentate gyrus of those animals with control grafts lacked AChE reactivity, further analysis was not conducted at the ultrastructural level.

\section{Discussion}

Delivery of $N G F$ in vivo

Septal neurons that stain immunohistochemically for ChAT and NGF receptor are dependent on the availability of exogenous 

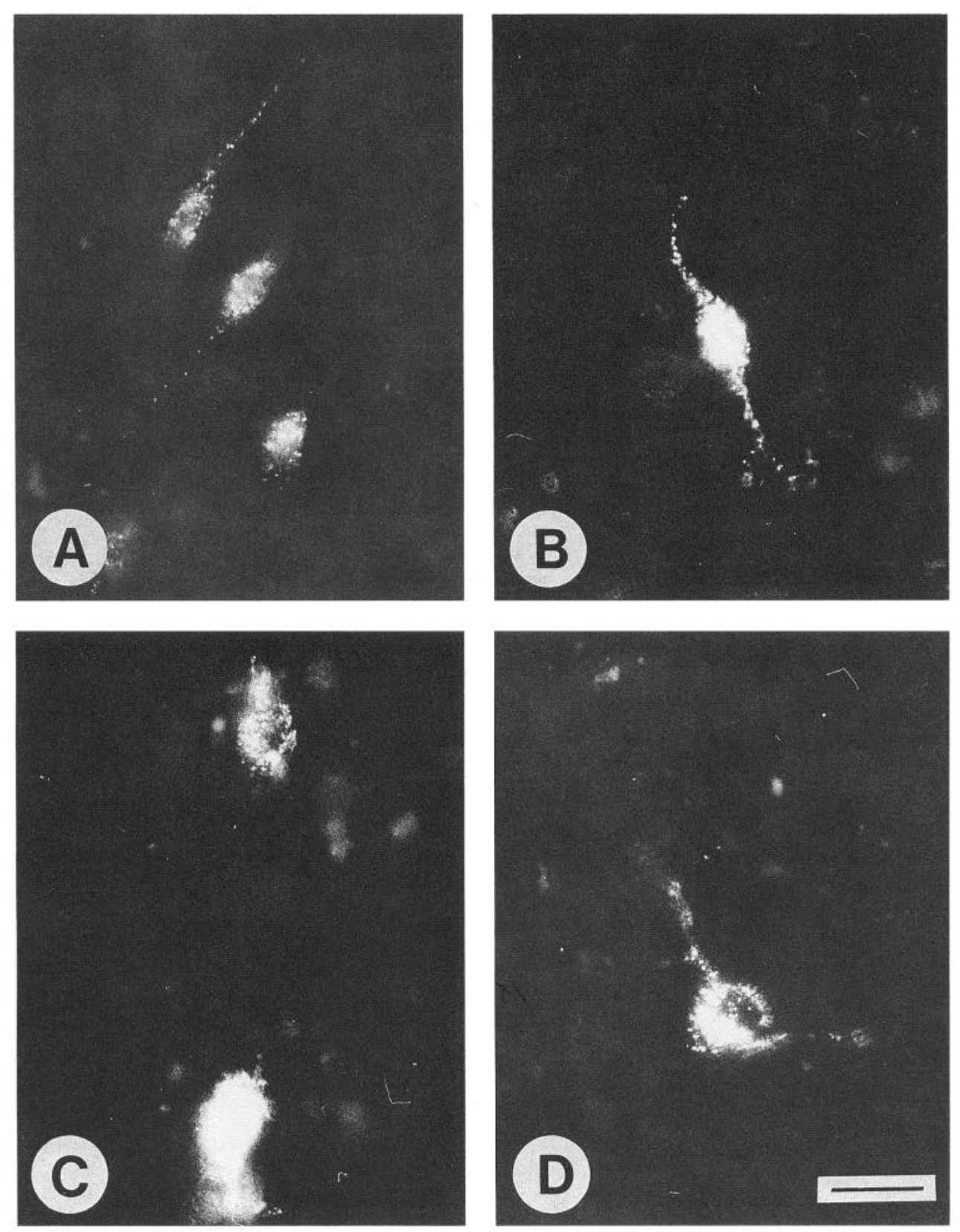

Figure 9. Retrogradely labeled septal neurons following stereotaxic placements of fluorescent microspheres in the dentate gyrus, 8 weeks after the animals received unilateral $\mathrm{FF}$ lesion and implants of NGF-producing collagen/fibroblast grafts. Elongated neurons possessing the fluorescent label are present in the ipsilateral medial septum/diagonal band $(A, D)$, contralateral diagonal band $(B)$, and septal midline $(C)$. Scale bar, $50 \mu \mathrm{m}$.
NGF for survival following axotomy in rats (Hefti, 1986; Williams et al., 1986; Kromer, 1987; Gage et al., 1988a; Montero and Hefti, 1988) and nonhuman primates (Koliatsos et al., 1990; Tuszynski et al., 1990). Exogenous NGF can be delivered within the brain by means of a miniosmotic pump that releases small amounts of NGF into the ventricular cavity or directly into the parenchyma. Investigations using this approach have revealed that exogenous NGF can maintain lesioned cholinergic neurons of the septal area $(\sim 90 \%$ in rats and $\sim 80 \%$ in nonhuman primates). There are, however, several drawbacks to the long-term use of these miniosmotic pumps. First, the biological activity of NGF stored within the reservoir may diminish over extended periods. Further, only a finite amount of NGF can be stored within the reservoir, and thus new NGF must be added periodically. The infusion of NGF via a cannula within the ventricle or parenchyma results in chronic damage of the tissue, and may also lead to infection. Finally, mechanical problems may be encountered with miniosmotic pumps.

Genetically modified fibroblasts that produce NGF offer an alternative approach to achieve a local delivery of this trophic substance to rescue lesioned septal neurons. In fact, these cells can act as "biological minipumps" that require a one-time placement within the brain. To date, allografts of rat $208 \mathrm{~F}$ and xenografts of mouse NIH-3T3 fibroblasts, both infected with retroviral vectors containing the cDNA for $\beta$-NGF in vitro and subsequently implanted within the lateral ventricle near the perturbed septum of rats, sustained over $90 \%$ of axotomized cholinergic neurons up to 2 weeks (Rosenberg et al., 1988; Strömberg et al., 1990). Data from this investigation reveal that grafts of NGF-producing primary fibroblasts can likewise support the survival of axotomized septal neurons, albeit to a lesser degree $(\sim 65-75 \%)$. Using primary cells to deliver NGF 

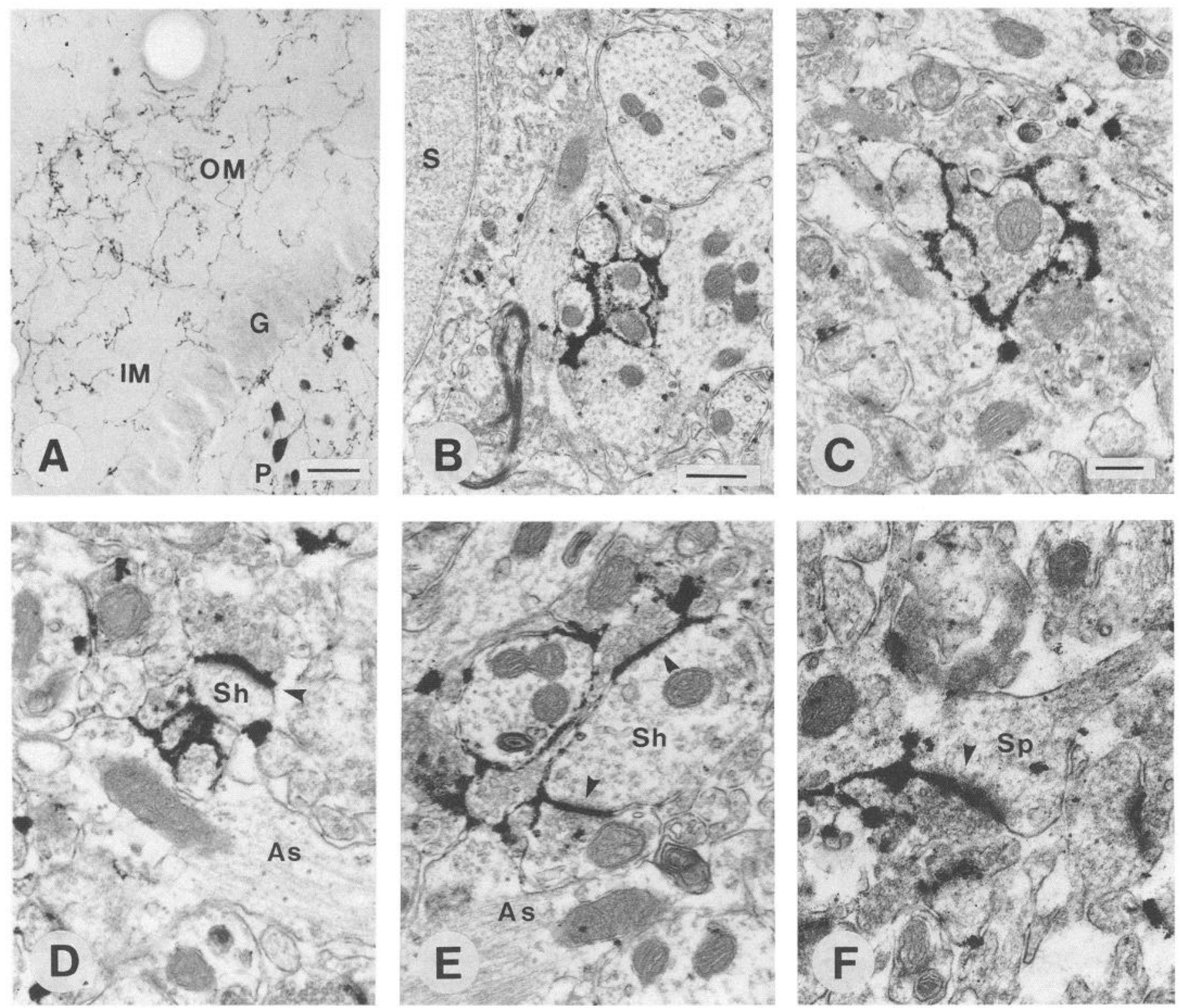

Figure 10. Topographical $(A)$ and synaptic $(B-F)$ distribution of AChE activity within the dentate gyrus 8 weeks after FF ablation and implants of NGF-producing fibroblasts in a collagen matrix. $A$, A coronal section $(40 \mu \mathrm{m})$ of the dentate gyrus stained for AChE, taken immediately adjacent to that tissue examined at the ultrastructural level. AChE-positive fibers are evident in the inner $(I M)$ and outer $(O M)$ molecular layers and granular layer $(G)$. AChE-positive somata and fibers are also found in the polymorphic layer $(P) . B$ and $C$, Clusters of AChE-positive unmyelinated axons are found throughout granular $(B)$ and molecular $(C)$ layers. $S$, soma of granular neuron. $D-F$, AChE-positive terminals form synaptic contacts (arrowheads) with dendritic shafts $(S h)$ and spines $(S p)$ in the molecular layers. Astrocytic processes $(A s)$ are usually seen near clusters of AChEpositive axons and terminals in the dentate gyrus. Scale bars: $A, 25 \mu \mathrm{m} ; B, 0.5 \mu \mathrm{m} ; C, 0.25 \mu \mathrm{m}$ (for $C-F$ ).

within the rat CNS has two particular advantages over immortalized cell lines. First, intrastriatal grafts of primary skin fibroblasts maintain a constant size between 4 and 8 weeks, and show no propensity to form tumors up to 6 months after implantation (Kawaja et al., 1991; Kawaja and Gage, 1992). Grafts of immortalized cell lines, on the other hand, often give rise to tumors following implantation within the brain. For instance, rat $208 \mathrm{~F}$ cells create large intraventricular grafts 2 weeks after implantation, yet by 4 weeks these grafts atrophy significantly (M. B. Rosenberg and F. H. Gage, unpublished observations). Although Strömberg et al. (1990) did not report the growth of grafts composed of 3T3 cells in vivo, recent data from Horellou et al. (1990) revealed that NIH-3T3 cells genetically modified to produce TH form large intracerebral tumors. Thus, the possibility of tumorigenesis by immortalized cell lines grafted into the brain remains problematic. Second, histocompatibility of donor cells with the recipient nervous system may be an important factor determining the long-term survival of cells not derived from the host (for review, see Widner and Brundin, 1988). Autologous and isologous grafts of primary skin fibroblasts survive up to 8 weeks and 6 months in the striatum of Sprague-Dawley and Fischer 344 rats, respectively (Kawaja et al., 1991; Kawaja and Gage, 1992). Equally important is the fact that the grafts appear viable and contain numerous fibroblasts. The survival of these grafts appears to be promoted through the histocompatibility between the donor and recipient. 
One plausible explanation for the atrophy of allografts of rat 208F cells observed 4 weeks after implantation (Rosenberg and Gage, unpublished observations) may be immune rejection. The survival of mouse NIH-3T3 cells in the rat brain, as reported by Strömberg et al. (1990), can only be sustained through daily immunosuppression therapy. In conclusion, we suggest that using primary cells for gene transfer and intracerebral grafting is one approach to obviate concerns of tumor formation and histoin compatibility often associated with immortalized and transformed cell lines.

\section{$N G F$-induced cell savings}

Results from the present investigation reveal that grafts of NGFproducing primary fibroblasts are able to prevent a significant percentage of NGF receptor-positive neurons from cell death following axotomy. Thus, as with infusions of exogenous NGF into the lateral ventricle (Hefti, 1986; Williams et al., 1986; Kromer, 1987; Gage et al., 1988a; Montero and Hefti, 1988) or grafts of NGF-producing immortalized fibroblasts (Rosenberg et al., 1988; Strömberg et al., 1990), intracerebral grafts of NGFproducing primary fibroblasts can successfully sustain perturbed septal neurons. The percentage of cells saved with NGF-producing primary fibroblasts, either injected directly within the septal parenchyma $(\sim 75 \%)$ or suspended within a collagen matrix and placed in the lesion cavity $(\sim 65 \%)$, is much lower than that achieved with either intraventricular infusions of NGF or implants of NGF-producing immortalized fibroblasts (both strategies sustain over $90 \%$ ). Assuming the rates of NGF release from genetically modified cells in vivo are similar to those in vitro, grafts of $208 \mathrm{~F}$ cells and primary skin fibroblasts secrete 0.2 and $0.5 \mathrm{ng} / \mathrm{hr}$, respectively (Yoshida and Gage, unpublished observations). Despite a higher rate of NGF production in vilro by primary fibroblasts over immortalized $208 \mathrm{~F}$ cells, the immortalized cells are able to sustain a larger proportion of axotomized cholinergic/NGF receptor-positive neurons of the medial septum than the primary fibroblasts. One reason may be that genetically modified primary fibroblasts, but not immortalized fibroblasts, downregulate the expression of the transgene following implantation (Palmer et al., 1991; Scharfmann et al., 1991). Another possible explanation for this disparity may be the dose of NGF delivered to axotomized ncurons with both types of grafted cells. On the one hand, immortalized cells tend to form tumors following intracerebral grafting, thereby exhibiting robust proliferative activity ( $208 \mathrm{~F}$ cells, Rosenberg et al., 1988; 3T3 cells, Horellou et al., 1990). On the other hand, primary fibroblasts grafted into the rat brain do not give rise to intracerebral tumors. In fact, we suspect that the population of primary cells between 3 and 8 weeks after grafting is smaller than that initially implanted (Kawaja and Gage, 1992). Thus, it is likely that different in vivo growth patterns of immortalized and primary cells directly influence the collective levels of NGF production by these intracerebral grafts; that is, higher rates of cell growth result in higher levels of collective NGF production. This proposal is supported by the fact that exogenous NGF released from miniosmotic pumps at a rate of $12.5 \mathrm{ng} / \mathrm{hr}$ (a rate more than 25 times that assumed to be initially released from genetically modified cells) also rescues over $90 \%$ of lesioned cholinergic neurons within the rat septum (Gage et al., 1988a).

Although implants of NGF-producing primary skin fibroblasts have a significant effect on the survival of axotomized NGF receptor-positive neurons of the rat septum up to 4 weeks, such grafts do not influence the size of immunoreactive perikarya. Following unilateral ablation of the FF and intraventricular infusions of NGF, no significant changes in cell size were evident among cholinergic neurons in the ipsilateral medial septum 2 weeks after perturbation (Gage et al., 1988a). These data from Gage et al. (1988a) and from the present investigation reveal that axotomized cholinergic/NGF receptor-positive neurons of the medial septum are of comparable size to unlesioned neurons, and that NGF does not significantly alter the size of axotomized septal cholinergic ncurons at thesc doses. Recently, Koliatsos et al. (1990) reported that lesioned cholinergic perikarya within the primate septum undergo marked hypertrophy in response to very high doses of NGF (a total of $5 \mathrm{mg}$ ). However, in a similar paradigm of chronic infusions of NGF (180 $\mu \mathrm{g} / \mathrm{ml}$ ) in the primate ventricle, Tuszynski et al. (1990) reported no obvious hypertrophy of axotomized septal neurons. While it remains to be determined whether lesioned cholinergic neurons of the rat septal area would exhibit a similar increase in cell size in response to high levels of NGF, these data suggest that hypertrophy of perturbed cholinergic neurons of the septum is inducible at high doses of NGF.

\section{$N G F$-induced axon growth}

One of the hallmarks of the adult mammalian CNS is that new axons generated following perturbation can only grow a relatively short distance within the brain (Ramon y Cajal, 1928). There are several hypotheses as to why axons of adult neurons are unable to regenerate in response to damage. First, injury within the adult brain induces astrocytes to proliferate, hypertrophy, and contribute greatly to the formation of scar tissue (for review, see Reier et al., 1989). Such astrocytic scars are unable to provide a conducive substrate for axon elongation, and thus appear to act as a physical impediment to regrowing axons (Brown and McCough, 1947; Clemente, 1955; Windle, 1956; Reier et al., 1983; Liuzzi and Lasek, 1987). Second, myelin-associated substances released following damage to brain have been shown to inhibit axon growth in vitro (Schwab and Caroni, 1988; Schwab, 1990). Finally, a lack of axonal regeneration in the adult CNS may be due, in part, to inadequate levels of trophic or trophic molecules that induce neuronal regeneration and promote axon growth, respectively (Reier et al., 1989). Despite these many factors that may impede axon regeneration within the adult brain, certain neurons in the rat CNS, especially retinal ganglion neurons and septal cholinergic neurons, exhibit a remarkable potential to extend new axons into various types of grafts, including segments of autologous peripheral nerve (David and Aguayo, 1981; Benfry and Aguayo, 1982; Hagg et al., 1990a), cultured Schwann cells within a collagen matrix (Kromer and Combrooks, 1985), embryonic rat hippocampus (Kromer et al., 1981; Tuszynski et al., 1990), and human amnionic membrane (Davis et al., 1987; Gage et al., $1988 \mathrm{~b})$. Although these different tissues are able to provide permissive substrates (e.g., Schwann cells, laminin) for regrowing axons of retinal ganglia and/or septal cholinergic neurons, regeneration of most damaged CNS axons remains impaired due to one or more of the following: the formation of astrocytic scars, the presence of myelin-associated inhibitory proteins, or a paucity of cither growth factors or substrate-specific molecules.

As mentioned, a number of different types of tissues have been successfully used to bridge new axon growth from septal neurons to the deafferented dentate gyrus. While grafts of autologous sciatic nerve, cultured Schwann cells within a collagen 
matrix, fetal rat hippocampus, and human amnionic membrane are all able to provide a conducive environment for regenerating axons of rat septal neurons, the time period necessary for axons to traverse the graft and extend into the hippocampus varies considerably. Septal axons appear to grow best within grafts containing Schwann cells and reach the hippocampus as early as 1 month after surgery (Kromer and Cornbrooks, 1985; Hagg et al., 1990a). With human amnionic tissue (Davis et al., 1987; Gage et al., 1988b) and fetal rat hippocampus (Kromer et al., 1981; Tuszynski et al., 1990), AChE-positive septal fibers within the deafferented hippocampus are observed at 8 weeks and 3 months, respectively. Grafts of NGF-producing fibroblasts within a collagen matrix also support the growth of new septal fibers, such that a sparse reinnervation of the hippocampus is evident as early as 4 weeks. By 8 weeks, the density of axons within the hippocampus is clearly greater than that seen at 4 weeks. Implants of noninfected cells in collagen offer little or no support, since the ingrowth of septal AChE-positive fibers to the hippocampus is negligible and no labeled cells are found in the septal area ipsilateral to the dentate gyrus following placements of retrograde tracer. Together, these data reveal that septal axons are able to use many different graft environments, including NGF-producing collagen/fibroblast matrices, for growth.

An important question that remains to be addressed is whether the regeneration of NGF-sensitive axons can occur in the presence of conducive substrates alone, or if NGF is a requirement to promote and maintain the new growth of septal axons in the adult brain. In the case of peripheral nerve grafts, Schwann cells are not only preferred substrates for axon growth (Fallon, 1985), but are also a cellular source of NGF (Heumann et al., 1987; Matsuoka et al., 1991). Although grafts of acellular peripheral nerve cannot support the growth of regenerating axons (Berry et al., 1988; Smith and Stevenson, 1988; Hagg et al., 1991; cf. Sketelj et al., 1989), recent evidence has shown that pieces of acellular sciatic nerve incubated in a solution of NGF for $24 \mathrm{hr}$ prior to implantation can serve as a viable environment for growing septal axons after ablation (Hagg et al., 1991). Further, the degree of hippocampal reinnervation by septal fibers achieved with grafts of fetal hippocampal tissue can also be augmented with concomitant infusions of NGF (Hagg et al., 1990b; Tuszynski et al., 1990). Our data indicate that collagen grafts containing primary skin fibroblasts induce a similar ingrowth of capillaries with basal lamina, astrocytes, and Schwann cells, regardless of whether the primary cells are noninfected or genetically modified to produce NGF. Also, the extracellular matrices of both types of grafts are similar, such that the patterns of laminin immunostaining and collagen distribution are comparable. The real differences between NGF-producing grafts and control grafts lie in the markedly increased degree of $\mathrm{AChE}$ staining and the abundance of unmyelinated axons within the former grafts. Prominent AChE reactivity is evident only in NGF-producing grafts; control grafts usually lack AChE staining. Both types of grafts, however, possess a sparse population of TH-immunoreactive fibers, as well as axons enveloped within Schwann cells and their processes; we suggest that most axons associated with these glial elements represent TH-positive sympathetic ingrowth. Furthermore, NGF-producing grafts possess numerous axons that are ensheathed by astrocytic processes, pass along the basal lamina of capillaries and astrocytes, or extend within the loose arrangements of collagen. Control grafts, on the other hand, possess only a very small population of axons within the extracellular environment. From these collective data, it appears that NGF-sensitive axons arising from perturbed septal neurons require NGF and a permissive graft environment for new growth. Using grafts of genetically modified cells that produce NGF in vivo, we have shown that regenerating septal axons will grow on a variety of different substrates only in the presence of NGF. Without elevated levels of NGF, axons do not regenerate in response to control grafts consisting of collagen and noninfected fibroblasts, even though the same cellular and extracellular substrates are available.

Previous studies examining the regenerative capacity of septal cholinergic neurons in the rat following axotomy and grafting have often referred to the "reinnervation" of the deafferented hippocampus with certain bridging grafts. To date, however, no investigation has provided direct morphological evidence that AChE-positive septal axons within the hippocampus actually innervate postsynaptic targets. Ultrastructural data from our study reveal that axons stained for AChE activity are sparsely distributed within the deafferented dentate gyrus 8 weeks after FF lesion and grafting of NGF-producing fibroblasts. These axons are often seen in clusters of two or more. The ultrastructural organization of $\mathrm{AChE}$-positive septal axons is similar to our recent observations that septal axons stained immunohistochemically for NGF receptor also form small aggregates within the normal rat dentate gyrus (Kawaja and Cage, 1991a). In addition, these newly formed $\mathrm{AChE}$-positive axons give rise to terminals that form synaptic contacts with dendritic shafts and spines in the deafferented dentate gyrus. The pattern of synaptic contacts between septal cholinergic axons and granular dendritic profiles is comparable to that normally found in the rat dentate gyrus; axosomatic contacts between cholinergic axons and granular neurons are rare (Shute and Lewis, 1966; Clarke, 1985). It is worth noting that when grafts of fetal septum are implanted within the adult rat dentate gyrus after FF ablation, cholinergic axons from the grafts innervate the somata of granular neurons at higher frequency than normal (Clarke et al., 1986). Further, the number of graft-derived cholinergic axons contacting dendritic profiles decreases dramatically (Clarke et al., 1986). These data suggest that while the cholinergic axons from fetal septal grafts within the deafferented dentate gyrus form unique synaptic arrangements with granular neurons, septal axons that regenerate across NGF-rich grafts of collagen and fibroblasts recapitulate at least some aspects of the normal synaptic organization within the dentate gyrus.

\section{References}

Anderson WF (1984) Prospects for human gene therapy. Science 226: 401-409.

Armstrong DM, Terry RD, Deteresa RM, Bruce G, Hersh LB, Gage FH (1987) Response of septal cholinergic neurons to axotomy. $J$ Comp Neurol 264:421-443.

Batchelor PE, Armstrong DM, Blaker SM, Gage FH (1989) Nerve growth factor receptor and choline acetyltransferase colocalization in neurons within the rat forebrain: response to fimbria-fornix transection. J Comp Neurol 284:187-204.

Benfry M, Aguayo A (1982) Extensive elongation of axons from rat brain into peripheral nerve grafts. Nature 296:150-152.

Berry M, Rees L, Hall S, Yiu P, Sievers J (1988) Optic axons regenerate into sciatic nerve isografts only in the presence of Schwann cells. Brain Res Bull 20:223-231.

Brown JO, McCough GP (1947) Abortive regeneration of the transected spinal cord. J Comp Neurol 87:131-137.

Chandler CE, Parsons LM, Hosang M, Shooter EM (1984) A monoclonal antibody modulates the interaction of nerve growth factor with PC12 cells. J Biol Chem 259:6882-6889. 
Chomczynski P, Sacchi N (1987) Single-step method of RN $\Lambda$ isolation by acid guanidinium thiocyanate-phenol-chlorofom extraction. Anal Biochem 162:156-159.

Clarke DJ (1985) Cholinergic innervation of the rat dentate gyrus: an immunocytochemical and electron microscopic study. Brain Res 360: 349-354.

Clarke DJ, Gage FH, Björklund A (1986) Formation of cholinergic synapses by intrahippocampal septal grafts as revealed by choline acetyltransferase immunocytochemistry. Brain Res 369:151-162.

Clemente CD (1955) Structural regeneration in the mammalian central nervous system and the role of neuroglia and connective tissue. In: Regeneration in the central nervous system (Windle WJ, ed), pp 147161. Springfield, IL: Thomas.

David S, Aguayo A (1981) Axonal elongation into peripheral nervous system "bridges" after central nervous system injury in adult rats. Science 214:931-933.

Davis GE, Blaker SN, Engvall E, Varon S, Manthorpe M, Gage FH (1987) Human amnion membrane serves as a substratum for growing axons in vitro and in vivo. Science 236:1 106-1109.

Fallon JR (1985) Preferential outgrowth of central nervous system neurites on astrocytes and Schwann cells as compared with nonglial cells in vitro. J Cell Biol 100:198-207.

Fisher LJ, Jinnah HA, Kale LC, Higgins GA, Gage FH (1991) Primary fibroblasts that produce L-DOPA: long term survival and behavioral effects when implanted in rats with 6-OHDA lesions. Neuron 6:371380.

Friedmann T (1989) Progress toward human gene therapy. Science 244:1275-1281.

Gage FH, Wolff JA, Rosenberg MB, Xu L, Ycc JL, Shults C, Friedmann $T$ (1987) Grafting genetically modified cells to the brain: possibilities for the future. Neuroscience 23:795-807.

Gage FH, Armstrong DM, Williams LR, Varon S (1988a) Morphologic response of axotomized septal neurons to nerve growth factor. J Comp Neurol 269:147-155.

Gage FH, Blaker SN, Davis GE, Engvall E, Varon S, Manthorpe M (1988b) Human amnion membrane matrix as a substratum for axonal regeneration in the central nervous system. Exp Brain Res 72: 371-380.

Hagg T, Vahlsing HL, Manthorpe M, Varon S (1990a) Septohippocampal cholinergic axonal regeneration through peripheral nerve bridges: quantification and temporal development. Exp Neurol 109: 153-163.

Hagg T, Vahlsing HL, Manthorpc M, Varon S (1990b) Nerve growth factor infusions into the denervated adult rat hippocampal formation promotes its cholinergic reinnervation. J Neurosci 10:3087-3902.

Hagg T, Gulati AK, Behzadian MA, Vahlsing HL, Varon S, Manthorpe M (1991) Nerve growth factor promotes CNS cholinergic axonal regeneration into acellular peripheral nerve grafts. Exp Neurol 112: 79-88.

Hedreen JC, Bacon JC, Price DL (1985) A modified histochemical method to visualize acetylcholinesterase-containing axons. J Histochem Cytochem 33:134-140.

Hefti F (1986) Nerve growth factor promotes survival of septal cholinergic neurons after fimbrial transections. J Neurosci 6:2155-2162.

Heumann R, Korsching S, Bandtlow C, Thoenen H (1987) Changes of nerve growth factor synthesis in nonneuronal cells in response to sciatic nerve transection. J Cell Biol 104:1623-1631.

Horellou P, Brundin P, Kalén P, Mallet J, Björklund A (1990) In vivo release of DOPA and dopamine from genetically engineered cells grafted to the denervated rat striatum. Neuron 5:393-402.

Kawaja MD, Gage FH (1991a) Nerve growth factor receptor immunoreactivity in the rat septo-hippocampal pathway: a light and electron microscopic investigation. J Comp Neurol 307:517-530.

Kawaja MD, Gage FH (1991b) Reactive astrocytes are substrates for the growth of adult CNS axons in the presence of elevated levels of nerve growth factor. Neuron 7:1019-1030.

Kawaja MD, Gage FH (1992) Morphological and neurochemical features of cultured primary skin fibroblasts of Fischer 344 rats following striatal implantation. J Comp Neurol 317:102-116.

Kawaja MD, Fagan AM, Firestein BL, Gage FH (1991) Intracerebral grafting of cultured autologous skin fibroblasts into the rat striatum: an assessment of graft size and ultrastructure. J Comp Neurol 307: 695-706.

Koliatsos VE, Nauta HJW, Clatterbuck RE, Holtzman DM, Mobley WC, Price DL (1990) Mouse nerve growth factor prevents degen- cration of axotomized basal forebrain cholinergic neurons in the monkey. J Neurosci 10:3801-3813.

Kromer LF (1987) Nerve growth factor treatment after brain injury prevents neuronal death. Science 235:214-216.

Kromer LF, Cornbrooks CJ (1985) Transplants of Schwann cell cultures promote axonal regeneration in the adult mammalian brain Proc Natl Acad Sci USA 82:6330-6334.

Kromer LF, Björklund A, Stenevi U (1981) Innervation of embryonic hippocampal implants by regenerating axons of cholinergic septal neurons in the adult rat. Brain Res 210:153-171.

Liuzzi FJ, Lasek RJ (1987) Astrocytes block axonal regeneration in mammals by activating the physiological stop pathway. Science 237: 642-645

Matsuoka I, Meyer M, Theonen H (1991) Cell-type-specific regulation of nerve growth factor (NGF) synthesis in non-neuronal cells: comparison of Schwann cells with other cell types. J Neurosci 11:31653177 .

Montero CN, Hefti F (1988) Rescue of lesioned septal cholinergic neurons by nerve growth factor: specificity and requirement for chronic treatment. J Neurosci 8:2986-2999.

Palmer TD, Hock RA, Osborne WRA, Miller AD (1987) Efficient retrovirus-mediated transfer and expression of a human adenosine deaminase gene in diploid skin fibroblasts from an adenosine deaminase-deficient human. Proc Natl Acad Sci USA 84:1055-1059.

Palmer TD, Thompson AR, Miller AD (1989) Production of human factor IX in animals by genetically modified skin fibroblasts: potential therapy for hemophilia B. Blood 73:438-445.

Palmer TD, Rosman GJ, Osbourne WRA, Miller AD (1991) Genetically modified skin fibroblasts persist long after transplantation but gradually inactive introduced genes. Proc Natl Acad Sci USA 88: 1330-1334.

Ramon y Cajal S (1928) Degeneration and regeneration of the nervous system. London: Oxford UP.

Reier PJ, Stensaas LJ, Guth L (1983) The astrocytic scar as an impediment to regeneration in the central nervous system. In: Spinal cord reconstruction (Kao CC, Bunge RP, Reier PJ, eds), pp 163-195. New York: Raven.

Reier PJ, Eng LF, Jakeman L (1989) Reactive astrocyte and axonal outgrowth in the injured CNS: is gliosis really an impediment to regeneration? In: Neural regeneration and transplantation (Seil FJ, ed), pp 183-209. New York: Liss.

Rosenberg MB, Friedmann T, Robertson RC, Tuszynski M, Wolff JA, Breakefield XO, Gage FH (1988) Grafting genetically modified cells to the damaged brain: restorative effects of NGF expression. Science 242:1575-1578.

Scharfmann R, Axelrod JH, Verma IM (1991) Long-term in vivo expression of retrovirus-mediated gene transfer in mouse fibroblasts implants. Proc Natl Acad Sci USA 88:4626-4630.

Schwab M (1990) Myelin-associated inhibitors of neurite growth and regeneration in the CNS. Trends Neurosci 13:452-456.

Schwab ME, Caroni $P$ (1988) Oligodendrocytes and CNS myelin are non-permissive substrates for neurite growth and fibroblast spreading in vitro. J Neurosci 8:2381-2393.

Sedgwick CJ (1980) Anesthesia for rabbits and rodents. In: Current veterinary practice, Vol 7, Small animal practice (Kick RW, ed), pp 706-710. Philadelphia: Saunders.

Seldon RF, Skuskiewicz MJ, Howie KB, Russell PS, Goodman HM (1987a) Implantation of genetically engineered fibroblasts into mice: implications for gene therapy. Science 236:714-718.

Seldon RF, Skoskiewicz MJ, Russell PS, Goodman HM (1987b) Regulation of insulin-gene expression: implications for gene therapy. Semin Med Beth Israel Hosp (Bost) 317:1067-1076.

Shimohama S, Rosenberg MB, Fagan AM, Wolff JA, Short MP, Breakefield XO, Friedmann T, Gage FH (1989) Grafting genetically modified cells into the rat brain: characteristics of $E$. coli $\beta$-galactosidase as a reporter gene. Mol Brain Res 5:271-278.

Shute CCD, Lewis PR (1966) Electron microscopy of cholinergic terminals and acetylcholinesterase-containing neurones in the hippocampal formation of the rat. Z Zellforsch Mikrosk Anat 69:334-343.

Sketelj J, Bresjanac M, Popovic M (1989) Rapid growth of regenerating axons across the segments of sciatic nerve devoid of Schwann cells. J Neurosci Res 24:153-162.

Smith GV, Stevenson JA (1988) Peripheral nerve grafts lacking viable Schwann cells fail to support central nervous system axonal regeneration. Exp Brain Res 69:299-306. 
St. I ouis D, Verma IM (1988) An alternative approach to somatic cell gene therapy. Proc Natl Acad Sci USA 85:3150-3154.

Strömberg I, Wetmore CJ, Ebendal T, Ernfors P, Persson H, Olson L (1990) Rescue of basal forebrain cholinergic neurons after implantation of genetically modified cells producing recombinant NGF. J Neurosci Res 25:405-411.

Tuszynski MH, Buzaski G, Gage FH (1990) NGF infusions combined with fetal hippocampal grafts enhance reconstruction of the lesioned septo-hippocampal projection. Neuroscience 36:33-44.

Widner $\mathrm{H}$, Brundin $\mathrm{P}$ (1988) Immunological aspects of grafting in the mammalian central nervous system. A review and speculative synthesis. Brain Res Rev 13:287-324.

Williams LR, Varon S, Peterson GM, Wictorin K, Fischer W, Björklund
A, Gage FH (1986) Continuous infusion of nerve growth factor prevents basal forebrain neuronal death after fimbria-fornix transection. Proc Natl Acad Sci USA 83:9231-9235.

Windle WF (1956) Regeneration of axons in the vertebrate central nervous system. Physiol Rev 36:426-440.

Wolf D, Richter-Landsberg C, Short MP, Cepko C, Breakefield XO (1988) Retrovirus-mediated gene transfer of $\beta$-nerve growth factor into mouse pituitary line AtT-20. Mol Biol Med 5:43-59.

Wolff JA, Fisher LJ, Xu L, Jinnah HA, Langlais PJ, Iuvone PM, O'Malley KL, Rosenberg MB, Shimohama S, Friedmann T, Gage FH (1989) Grafting fibroblasts genetically modified to produce L-dopa in a rat model of Parkinson disease. Proc Natl Acad Sci USA 86:9011-9014. 